\title{
From the archives
}

\section{Rhetoric and reform}

As rancorous as debates on health care reform have occasionally been of late, in some respects the rhetoric used to be more extreme. This excerpt from the September 1940 issue of CMAJ is from an essay written against the ominous background of war. For this writer the enemy takes the shape of reformers and bureaucrats. Although Canadians would learn that socialized medicine is not tantamount to a fascist state, the ideologic tension between individual rights and the collective good is still very much alive in current debate. - CMAJ

... The medical profession, dealing constantly and at first hand with all the intricacies of behaviour of the human mind and body, stands in a position which is unique in outlook and in opportunities - a position from which the weaknesses of a totalitarian approach must be immediately apparent .... .

$[\Pi]$ every economic question today there are undoubtedly two schools of thought - sharply distinct, and in the last analysis irreconcilable. The first ... still maintains an abiding faith in the good thinking of the ordinary citizen, still holds his right to liberty inviolable, sill demands the continued sanctity of the individual's rights of appeal from oppression and injustice ... and still views with profound distrust all those theoretical panaceas which are usually imposed by totalitarian planners with little experience in practical affairs. The other school ... at the behest of reformers sitting behind their desks, who would control the lives and destinies of all of us, seeks to place upon the statute books extensive sets of rules and regulations, which by their nature must ignore personal desires to a very large extent, and must in effect reduce every individual to an identification number in a "plan".

... In the larger and more dangerous sphere of international affairs we are now defending our democratic institutions against "aggressors", imbued with the totalitarian's craving to regulate and rule. Within Canada we must be equally on guard against the infiltration of similar regimentations into our private lives. ... It is now more than ever necessary to scrutinize plans of "reform" with a fearless vigilance, taking for our creed the Magna Charta and the Bill of Rights, and resisting the growth of dictatorial oppression in whatever form it may appear - unless we wish, sooner than we may think, to embrace the embryonic stage of a totalitarian economy. This viewpoint, of course, does not in the slightest degree underestimate the duty of every citizen to discharge his proper obligations to the State ... . But this does not mean, except in the extremest test of national survival, that the citizen has any need to become a voiceless pawn in a State manned by numberless comfortably salaried officials, one of whose main objectives quickly becomes the preservation of their own positions.

From: Wolfenden HH. Medical economics XI: A summary of the Canadian problem of medical economics. CMAJ 1940;43(3):274-8.

\section{Main}

I think the hardest part about being the senior medical resident is covering 4 Main at night.

4 Main is our palliative care unit. It is the place where kindness is recognized as more important than advanced cardiac life support algorithms. It is the place where morphine, not Timentin, ranks as the most prescribed drug. And, of course, it is the place where patients die from terminal illness.

It is not dying itself that bothers me. I have witnessed many patients on the medical ward die. Some go quickly and without warning; their bodies are found. Others are discovered in the process of dying, and their journey to the hereafter is delayed by the tubes and lines inserted by the code team. Of course, some go agonizingly slowly, praying only for release from their suffering as each sunset falls. Then there are those who go peacefully, as if in their sleep. Each of these deaths has its place, and I myself have a place in them. Laying stethoscope to silent chest is somehow a fitting close.

At 2 am I am paged to 4 Main because Mr. S. has died. I enter a room I do not know and find a family I do not know surrounding a man I do not know. I put my stethoscope to a chest that has never been alive to my ears and I find it deafeningly silent. I wave a flashlight in front of pupils that have never reacted to me, and they stare back accusingly. When I leave the room, the family is relieved that there is finally closure and an end to his suffering.

But for me, there is no closure on 4 Main. I wonder about the young woman at his bedside: Is she a niece, a granddaughter, or a second wife? I wonder about the small cuts on his finger: Was he an avid reader, or the victim of dry hospital air?

$\exists \quad$ Mr. S. should be the protagonist, but I do not know him well enough.

That is the problem with 4 Main.

\section{Beth-Ann Cummings}

Department of Internal Medicine

Sir Mortimer B. Davis - Jewish General Hospital

Montréal, Que. 